\title{
Screendance as a Question: All This Can Happen and the First Edition of the Light Moves Festival of Screendance
}

Priscilla Guy, Université de Lille 3

\begin{abstract}
This article aims to extend the idea that screendance is a set of dispositions and elements which can create a common practice for artists of various backgrounds. Instead of focusing on formal qualities and the type of works that may result from these, this review envisions screendance as a posture towards art making: a way of accessing new creative ideas, a way of looking at new and old artworks, a way of creating works, and a way of thinking. This review first provides an overview and assessment of the inaugural edition and curatorial framework of the Light Moves Festival of Screendance which took place in Limerick, Ireland in 2014 and which propels alternate ideas about screendance. This is followed by a critical review of Davies and Hinton's film All This Can Happen (2013), in particular its approach to narrative and the construction of meaning, to expand on the discussion. The review closes with a statement in favor of independent and experimental approaches within this rich playground where dance, performance, digital media, visual arts, and cinema meet.

The review was first published on the blog of the Centre for Screendance (November 2015) ${ }^{1}$ and is updated and reprinted here to draw attention to the interplay between curatorial approaches and creative practice.
\end{abstract}

Keywords: alternate perspectives, experimental approaches, discussion, extended definitions, critical review

Defining screendance (or dancefilm, or videodance, or dance on screen, or dance for the camera, or cine-dance, or moving-picture dance) ${ }^{2}$ as an artistic discipline is a divisive exercise that forces many of us to justify our word choice-an inherently defensive position. Instead of diving into the poetics of this eclectic form and its many entry points including choreography, movement, performance, virtual presence, and the moving image, such debate-related both to the materials used and to the methods of creation-has intensified the importance of the two primary artistic components of this practice: dance and cinema. Of course, such ontological dilemmas remain interesting in that they allow us to unpack some core concepts of the practice. Ultimately, however, we are stuck in a paradoxical position: while screendance calls for 
a dismantling of artistic categories, its denomination as a discipline in its own right ultimately encloses it in an uncomfortable box.

Wouldn't it actually be liberating to focus a little more on what screendance does, and less on what it is or is not? What if we take screendance as a question, instead of an answer? What if we don't consider the encounter between dance and cinema as an end, a discipline, or a hybrid form, but rather as a starting point, an experiment, a method, or a question?

Claudia Kappenberg, in her chapter "The Politics of Discourse in Hybrid Art Forms," 3 shares Hollis Frampton's concept of the "film machine." Frampton proposes to envision as one machine all parts that constitute a filmic work, i.e. to not only think of the camera used to capture moving images as one machine, or of the projector that projects those images to an audience as another one. Rather, the "film machine" would be the sum of the parts that constitute the artistic experience of cinema, from its making to its presentation.

Accordingly, Kappenberg suggests that,

We should perhaps be less concerned with individual projects and whether they are Screendance or not, but rather consider a wider body of works and even include that which occurs in the everyday through interactions with cameras and screens, digital media, and the internet. If a person is caught on a CCTV camera in a public building, perhaps this is also part of the contemporary machinery of Screendance. ${ }^{4}$

In doing so, Kappenberg invites us to look at the big picture of the practice, rather than its specific features.

My aim is to extend the idea that screendance is a set of dispositions and elements which can create a common practice for artists of various backgrounds. I will therefore give less importance to its formal qualities and to the type of works that should result from it. Instead, I will envision screendance as a posture towards art making: a way of accessing new creative ideas, a way of looking at new and old artworks, a way of creating works, and a way of thinking.

I had the opportunity to share these questions during the first edition of the Light Moves Festival of Screendance in Ireland, ${ }^{5}$ curated and directed by Mary Wycherly and Jürgen Simpson. This event was special in many ways. First, because the launch of a new international festival means that the field is further developing its networks and structures, and that more professionals are involved in its development. Second, because this festival's curatorial choices put forward works, conferences, and teaching approaches that proposed screendance as a starting point and a perspective, rather than as a fixed discipline. Amongst the films presented, All This Can Happen ${ }^{6}$ from Davies and Hinton represented this idea particularly well. 
I will first provide an overview and critical review of this inaugural edition of Light Moves. I will then comment critically on Davis and Hinton's film in order to illustrate my argument. Finally, I will close the discussion with a statement in favor of independent and experimental approaches within this very rich playground where dance, performance, digital media, visual arts, and cinema meet.

\section{First Edition of the Light Moves Festival of Screendance}

The Festival ${ }^{7}$ took place over four days, from November 6 through 9, 2014. It was organized around four axes: teaching (a two-day workshop), screenings, symposium, and discussions with the artists. Douglas Rosenberg made his keynote address, stating how important it was to welcome a new structure in the field and how precious those moments of beginnings were. He mentioned that, due to the hybrid nature of our field and its international-rather than geographical-development, moments of gathering were especially significant, as they allow for the sharing of knowledge and information. Through the choices made by the curators, debates and questions emerged, as well as affinities between the professionals attending the event. Those encounters are the fuel we need to continue our investigations, the mental and creative support that pushes us to innovate.

One of the most interesting things about Light Moves was the manner in which its curatorial choices challenged many common assumptions about screendance. The eternal question, "Was that dance at all?", was pronounced several times during the festival. Few films featured choreographed dance sequences performed by trained dancers, yet they all engaged with movement in a singular way. Dance was at the core of the festival, but in a different form than the one we are used to seeing in such settings. The attention given to the intersection of academia, creation, and pedagogy also reinforced a desire for a holistic comprehension of screendance.

\section{Short Films Highlights}

Amongst the short films presented, some stood out for their novel presentation of dance and movement. Vanishing Point ${ }^{8}$ proposed a minimalist transformation of a performance-installation. The hyper-slow evolution from frozen landscape to running water brought the spectator into a meditative state; bodies seemed lifeless and unmoving. Yet as the film evolved, details emerged: a subtle alteration of the set up, or the quiet movement in the sound-scape which pointed to the deterioration of the initial image. In contrast to the fast editing so common in advertising, music videos, and action cinema, this film challenged our conception of bodies in [slow]motion. Vanishing Point was not necessarily what one might call a "dancefilm," yet it fit in perfectly at this screendance event.

Nation for $T_{W}{ }^{9}$ featured a novel use of editing in order to put bodies into action. This stop-motion film presented two individuals diving underground in order to meet each 
other from opposite sides of the planet. Digging their way towards one another, their bodies were nearly absent from the film, although the spectator felt them traveling underground and saw the repercussions of their passage as the ground surface was displaced and destroyed by their movement. One can only imagine how it would feel to dig a tunnel underground, traversing sand, rocks, gravel, and grass; and when the two bodies finally emerged again, I, as a spectator, was left relieved, yet curious. This investigation was fascinating for its simplicity, and made real use of the cinematic potential to convey a choreographic idea involving movement of the human body.

Beach Party Animal ${ }^{10}$ traced pedestrian movement proper to Brighton beach life (UK) and transformed it into a dance, simply by juxtaposing a series of lightly staged everyday situations. From dog walkers to yogis, from moms with babies to an old man in a leopard g-string swimsuit, the characters in this hilarious episode were bursting with honesty. Simple gestures became choreographic when repeated or looked at from a different perspective. Normal behaviors became grotesque when seen through the eye of the camera. With its frank use of humor and dynamic dramaturgy, this film brought us into a more pedestrian expression of the body and its evocative features.

\section{Feature Films and Installations Highlight}

While most of the program was focused on short films, the curators also included feature films that addressed the question of movement and choreography in unexpected ways. With Russian Ark ${ }^{11}$ and Playtime, ${ }^{12}$ Light Moves brought together cinema lovers and screendance specialists. In doing so, they invited the spectators to discuss matters that are often neglected in screendance contexts-for instance, the physical body of the cameraperson or the choreography of architecture and props in relation to human bodies. Instead of screening films that correspond to the idea most people have of screendance, the two artistic directors pushed the audience to watch works with a specific mind set, indirectly asking them to consider where the dance was.

Installed in a gallery space as well as in a smaller room next to the screening space, video installations brought yet another layer to this question of screendance. Distant Wars ${ }^{13}$ proposed a video installation on an iPod with headphones, in which a collage of archival footage evoked the fear of war imposed on us by the State apparatus. People were documented, animated, and presented at a very small scale, putting the body of the spectator in the foreground. Alone in that small room, one could engage in a very personal way with the material for as long as one wished. Perception of time was altered and one could experience an intimate relationship with the [dancing] bodies on that small iPod screen. If the invader comes ${ }^{14}$ welcomed the viewer into a gallery space in which three screens were juxtaposed. Here again, the spectator was free to determine the duration of their experience. The piece evolved from one screen to another in a minimalistic way, with very few bodies in motion appearing on screen 
and a lot of space for contemplation and silence. Again, watching this piece with "screendance" in mind highlighted some of its most striking aspects: temporality and spatiality. I noticed how my eye was drawn to some details, some "possibilities," some "potentialities." So many things could have happened during the time spent watching this video installation, and yet it is an economic work, where less is shown and less is done. Though formal at first sight, this work manages to convey a real kinaesthetic charge and a subtle choreographic construction completely at odds with a more action-based or narrative dance-film style.

\section{Workshop and Symposium Highlights}

Finally, a two-day workshop and the symposium where also curated for this occasion. ${ }^{15}$ First, the workshop's facilitators/teachers offered a rich palette of approaches to screendance creation and theory, while introducing ideas that were later echoed at the symposium. Led by Douglas Rosenberg, Katrina McPherson, Simon Fildes, and Jürgen Simpson, the workshop brought together international filmmakers, performers, and choreographers. Each facilitator shared their personal vision on the practice, proposing exercises and questions of debate to the group. While those individual visions where sometimes divergent or even contradictory, the combination of these perspectives created a strong playground for the participants to further develop their own, personal approach to the field. The discrepancies emerging from the various backgrounds and profiles of the facilitators ultimately consolidated back into a common desire to challenge the field and to be challenged by other professionals. Their curiosity made up for any disagreement that might have weakened the workshop, highlighting the positive impact of envisioning screendance as a starting point, rather than a rigidly defined field. Second, the symposium gathered speakers from diverse countries and proposed a wide range of conferences, including both performative approaches and academic presentations. Experimentation, crossdisciplinary approaches, and alternate conference styles where at the core of the program.

Another key feature of the festival was the overwhelming majority of female scholars included in its symposium. Since its beginnings, cinema has had influential female artists and authors who were responsible for initiating some of the most groundbreaking techniques and ideas for the screen. However, their work and writings were not given as much attention as those of their male counterparts and were often forgotten or dismissed. Yet, some initiatives now try to reconnect the dots by retracing influential works by women in the film field, such as Robin Blaetz's book gathering several experimental women's work and practice. ${ }^{16}$ In Québec, the disparities observed in the field of cinema notably gave birth to the non-profit organization Réalisatrices Équitables in 2007, that strives to attain equity for women directors in Québec's film industry. ${ }^{17}$ Screendance, however, seems to have developed differently than the wider industry of cinema regarding this issue: several key artists and authors 
in the field are women, and their contribution to the milieu is often recognized. ${ }^{18}$ The current community of screendance is indeed witnessing a wide consolidation of women's writings and knowledge: symposiums, conferences, and panels often feature a large majority of women; peer reviewed publications (such as this one) also dedicate a high percentage of their articles to women scholars; a strong cohort of female directors emerge from screendance festivals and events; and, finally, major curators internationally are also in good proportion, women. And within our specialized circuit, festivals with a strong experimental component-such as Light Moves-seem to gather even more women in their programs. ${ }^{19}$

In terms of academia, this phenomenon within the screendance circuit has already had a significant impact on both the content of the artworks presented and the academic discourse that is being developed around it. This field is fed largely by alternate voices, namely, those of women who interact with the form on several levels (academic, artistic, curatorial, etc.). While those voices don't get as much exposure or opportunities in male-dominated experimental and commercial cinema festivals, they decidedly grow in number in our specialized niche and offer marginal perspectives to audiences, artists, and scholars.

Light Moves $^{20}$ thus inscribes its curatorial vision in the international network in a political way, instigating new debates and creating space for alternate voices. Working as a counterpoint to mainstream cinema, the festival incarnates an important fringe of the screendance's network-one that is resolutely experimental, searching for new connections or marginal discourses, and digging further under the surface of commercial excitement.

\section{Curating Screendance}

Curators Mary Wycherly and Jurgen Simpson made risky choices, putting forward experimental approaches instead of mainstream ones. Worldwide, a lot of screen time is dedicated to mainstream 'dancefilms' in the festivals circuit, while little space is reserved for experimentation in screendance, on both formal and conceptual levels. For instance, established festivals such as San Francisco Screendance Festival and Dance on Camera Festival in New York feature a great percentage of films that have more in common with the commercial film circuit. On an artistic level, those (more often than not) high-budget productions seem to come with a certain image quality and a certain camera work: HD or 3D images, stable camera, long shots with steady cam, impressive bird-eye views, expensive slow motion shots, etc. In addition, those films frequently feature a certain type or style of dance, and more or less codified expressions of moving bodies as in ballet vocabulary, acrobatic movements and circus techniques, modern dance technique, social dance, etc. Those films move away from experimental approaches to movement and camera work, and render a homogenized version of screendance, one that is somehow reduced to a recognizable "style" or 
"type" of dance, filmed with the visual qualities of Hollywood movies with an impressive production team. To counter balance such expressions of screendance in the art milieu, alternate platforms are needed. Not only should they feature marginal approaches to both dance and cinema, and create space for independent filmmaking/choreography, to challenge the dominant forms of cinema.

For all these reasons, I find Light Moves to be an important new player in the larger circuit. This festival creates space for strong voices that have been present in the field for decades, and highlights them with audacity through a bold program of films, installations, conferences, and workshops. In addition to positioning themselves in a dynamic and competitive international film festival circuit, Light Moves' curators integrate their event in a growing alternate circuit that gathers symposiums, festivals, scientific publications, and other projects through which a community of artists and researchers find a sense of belonging outside the mainstream standards. Annually, a series of encounters and events are now available to professionals interested in experimentation and alternate visions of screendance, in several countries. The development of this international community becomes a statement against normalized approaches in cinema and dance and in the arts in general. ${ }^{21}$ In parallel, the two curators deal with a diverse audience, ranging from specialists in the field to citizens of the City of Limerick who may not already be familiar with screendance. The curators manage to present a radical program, while also gathering diverse audience members together around some cinema classics, which are re-considered under the "lens" of screendance (e.g. Russian Ark, Playtime). ${ }^{22}$ In the program notes, Wycherly and Simpson mentioned their desire to present an array of approaches, while also "providing a platform for new works and a forum for development and enquiry in this exciting area." 23 They aim to "showcase the unique diversity of movement on screen via a series of curated events." 24

While the distinction between curating and programming is being debated and questioned in the art sphere, Light Moves proves that there is a need and a place for strong curatorial voices in the field and that audiences' engagement with such voices is enthusiastic. Traveling from film to video installations, from classic cinema to an intimate iPod screen, the viewer may enlarge their range of perception and discover new sensations.

\section{All This Can Happen / Davies and Hinton, UK, 2012}

In the midst of this rich programming, All This Can Happen ${ }^{25}$ engaged with most of the more exciting questions debated during the festival. Even the title of the film seemed to point to the very concerns of the participants, reassuring them that, yes, all this can happen [as screendance]. Put into that context, the film incarnated several alternative visions of choreography for/by/with cinema, without actually making explicit references to "dance." Yet one could argue that this film had many dances in it: a 
dance of moving images, from shot to shot; a dance made out of cinematic potential and editing strategies; and a dance in which body movements are not choreographed by a choreographer during the shooting, but rather by the choreographic choices of the two editors in post-production.

\section{Choreographic Editing}

In All This Can Happen, made out of archival images and footage from the earliest days of cinema, several choreographic strategies are at play: repetition, creation of a trajectory, and juxtaposition of bodies through the use of split screens. Temporality and spatiality are at the center of the choreographic qualities of this work.

Karen Pearlman, in her book Cutting Rhythms: Shaping the Film Edit, compares the way choreographers work with the way editors do, mentioning how movement is actually created and choreographed "within a shot, through the juxtaposition of shots, or both." ${ }^{26}$ Movement expresses duration: time goes by and modifies our reception of a movement, just as time goes by and modifies the movement itself as it ends, continues, slows down, or accelerates. She writes, "Editing involves the phrasing of movement, or the aesthetic shaping of movement into that aspect of empathetic engagement with film that we call rhythm." ${ }^{27}$

In All This Can Happen ${ }^{28}$ the creators play with choreographic material composed of bodies, landscapes, architectures, vehicles, animals, nature, and everyday objects. From this vibrant palette, rhythm is built and space is sculpted. Davies and Hinton choreograph the screen using the cinematic parameters of film; its temporal potential is exploited through a precise editing that interrupts, repeats, accelerates, and decelerates actions with a tempo that keeps the viewer captive. Its spatial potential is multiplied and confused through the use of the split screen, making the action jump from one place to another-or happen in two distinct places at the very same timewhile remaining in constant dialogue. A shot from the right side of the screen interacts with a shot from the left side of the screen. Movement is choreographed within those shots, but also for the relation they have to one another. Still shots cohabit with moving images, creating another type of tension between stillness, movement, and the potential of the still image to move again. Like in a painting, one's eye is guided through the composition of moving elements on screen. A new reality is choreographed through dramaturgic choices and a fine orchestration of time/space.

Similar to the work of Dutch documentary filmmaker Johan Van der Keuken, (who is not considered a screendance maker at all, but who produced many films that have a strong choreographic feel), ${ }^{29}$ All This Can Happen invents new dances, new bodies, and new locations that can only exist in the reality of the film. Like Van der Keuken, Davies and Hinton make a dance without dancers. From a choreographic editing perspective, this achievement is another step in the blurring of artistic disciplines to the profit of singular artistic voices. 


\section{Narration and Coherence}

Another element that is dominant in this work is the use of a voice-over throughout the film. While at first this voice-over seems to guide us through the chronology of the images, it quickly becomes clear that it is neither a reference for a chronological storyline, nor a descriptive voice. The voice here acts as another body in the film, sometimes incarnating a character that we see on screen, at other times acting as a feeling, a texture, or even a nostalgic presence. Those various identities are intertwined, dismantling and reconstructing several possible storyline associations. Fiction cinema has often been put at odds with experimental filmmaking, notably because of the question of narration. Also, "narration" is frequently thought to provide chronological "coherence." While several feminist filmmakers discarded narration for the benefit of abstraction in the '70s, hoping to reinvent representations of the female body and liberate themselves from the rules of Hollywood cinema, some scholars such as Laura de Lauretis envisioned narration differently. Shohini Chaudhuri writes:

De Lauretis points out that the closure is only a contingent feature of narrative, particular to certain forms such as the Hollywood classic. More important to her is the fact that narrative is a mechanism of coherencethat is, a mechanism of meaning. She advocates the strategic deployment of narrative in order to 'construct other forms of coherence, to shift the terms of representation, to produce the conditions of the representability of another-and gendered-social subject. ${ }^{\prime 30}$

Chantal Akerman, in her very first film Saute ma Ville ${ }^{31}$ created a mechanism of coherence that borrowed from linear narration, while using no dialogue at all and giving very few indications about the character's history. The film presents a woman going up an elevator, entering her house, preparing for some disaster (taping the doors, blocking the windows), then "cleaning" the kitchen while throwing Tupperware on the floor, awkwardly eating spaghetti, putting water on the gas oven, lighting it up, and sitting on the floor... This sequence of actions, apparently random, slowly organizes into a coherent whole, even though it might not happen chronologically on screen. From a state of latent hysteria, the woman seems to find some internal peace through this mysterious ritual. No narrator is present in the film, yet the woman makes sounds, sings creepily, and talks to herself-offering glimpses of her internal thoughts to the viewer. While Saute ma Ville is not carried by a typical voice-over, the mumbling and singing of the main protagonist acts as a strong expression of her emotional states. Without actual words, this form of vocal presence in the soundscape also reinforces another form of logic and narration in the film.

The actual actions she performs and her mental state converge in a coherent whole. Saute ma Ville is probably not included in any screendance repertoire, yet it has many features that allow us to relate it to both dance/performance. Movement is central, 
carried on by a logic that creates meaning, while no dialogue or character are clearly presented or described. The choreographed sequences of actions recall Chaplin's films, albeit with a much more "trash" aesthetic.

Davies and Hinton's film holds similarities with Akerman's work in Saute ma Ville, challenging our conceptions of narration, while using a form of voiceover that differs from a linear storyline. This voice in All This Can Happen is notably poetic, not only prescriptive. Here the voice is integrated into the choreographic editing and neither the voice nor the movement is subordinate. Instead, they collaborate in the creation of coherence throughout the film. The viewer might look forward to actually seeing the face of the voice they hear, chasing the subject or principal actor of the film, and getting lost in his memories and stories instead. All This Can Happen succeeds at establishing a dialogue between bodies and voice, images and content. Meaning is created through the succession of images, sound, and text from shot to shot, and through an accumulation of those same elements within shots. From a screendance perspective, it stands out as a strong model for the development of new strategies for building interaction between dance and other languages.

\section{Conclusion}

In conclusion, both the Light Moves Festival of Screendance and Davies and Hinton's film suggest a wider understanding of screendance: its position in the field of contemporary arts challenges both dance and cinematic conventions, while also putting screendance in dialogue with other art forms. Indeed, if screendance remains a question-one that leads us to think outside the box or to connect ideas in a novel fashion - then there is no limit to its creative potential.

Experimental filmmaking and contemporary creation in dance are not simply pushing forward the formal qualities of the medium, but also our understanding of them. Experimentation demands that we dare to imagine new ways of working, not just new categories within which to operate. The strength of experimental creation is an oscillation between knowing where we are going and not knowing what we are doing, even at the moment we do it. Like walking, which is a constant adjustment, a constant fall-and-recovery, these works are impossible to envision if we don't allow ourselves to fall in the first place. Experimental creation demands that we get lost from time to time. Posing screendance as a question seems an interesting way to revisit some cinema classics, while being a strong tool to envision creation and innovation in this field of creativity. 


\section{Biography}

Priscilla Guy is a multidisciplinary artist and academic researcher based in Montreal (Canada). She is founder of Mandoline Hybride, a company that creates screendance projects, site specific choreographies, and multidisciplinary stage performances. Mandoline Hybride has presented works internationally since 2012.

Priscilla Guy participates in the development of crossings between dance and cinema, and collaborates on international publications such as The Oxford Handbook of Screendance Studies, The International Journal of Screendance, La creación híbrida en videodanza and The Dance Current. She is currently a PhD candidate in cinema at Université de Lille 3 (France).

Email: mandolinehybride@gmail.com

Website: http://www.mandolinehybride.com

\section{Notes}

${ }^{1}$ Guy, "Review of the 1st Edition of Light Moves Festival."

${ }^{2}$ Carroll, "Toward a Definition of Moving-Picture Dance."

${ }^{3}$ Kappenberg, The politics of discourse.

${ }^{4}$ Ibid. 25.

${ }^{5}$ Light Moves Festival, November 2014.

${ }^{6}$ All This Can Happen, Davies \& Hinton.

${ }^{7}$ Light Moves Festival, November 2014.

${ }^{8}$ Vanishing Point, Hecher, Beate, and Keim.

${ }^{9}$ Nation for Two, Hertog and Nadler.

${ }^{10}$ Beach Party Animal, Aggiss and Murray.

${ }^{11}$ Russian Ark, Sokurov.

12 Playtime, Tati.

${ }^{13}$ Distant Wars, Edmunds.

${ }^{14}$ If the Invader Comes, Dobowitz and O Conchuir.

${ }^{15}$ Light Moves Festival, November 2014.

${ }^{16}$ Blaetz, Women's Experimental Cinema.

17 Réalisatrices Équitables aspires to a more equitable space for female directors' concerns, world vision, and imagination on all our screens. Réalisatrices Équitables is deeply concerned by women's image in the media. To this end, RÉ seeks to heighten awareness in the media arts community with regards to reducing gender stereotypes by diversifying male and female characters written and brought to life by creators here and abroad. (Réalisatrices Équitables). 
${ }^{18}$ Since the imprint in the 1940s of Maya Deren. who is one of the most famous figures of early screendance discourses, one notices numerous great female artists, teachers, and thinkers who marked history and have contributed to the establishment of screendance practices/theories.

${ }^{19}$ For instance, the International Videodance Festival of Burgundy (France), which also has an alternate curatorial signature had an academic panel constituted only of women for its May 2015 edition (International Videodance Festival).

${ }^{20}$ Light Moves Festival November 2014.

${ }^{21}$ In addition to the Videodance Festival of Burgundy (France) mentioned above, one can also think of International Screendance Festival in Durham (USA) and Festival Itinerante Agite $Y$ Sirva (Mexico), two other examples that gather alternate voices of theoreticians, practitioners, and curators at the heart of their curating preoccupations. (International Videodance Festival of Burgundy; International Screendance Festival in Durham; Festival Itinerante Agite Y Sirva).

${ }^{22}$ Russian Ark, Sokurov; Playtime, Tati.

${ }^{23}$ Light Moves Festival (online).

${ }^{24}$ Ibid.

${ }^{25}$ All This Can Happen, Davies \& Hinton.

${ }^{26}$ Pearlman, Cutting Rhythms, 41.

${ }^{27}$ Ibid.

${ }^{28}$ All This Can Happen, Davies \& Hinton.

${ }^{29}$ Such as Temps/Travail (1999); On Animal Locomotion (1994).

${ }^{30}$ Chaudhuri, Feminist Film Theorists, 69.

${ }^{31}$ Saute ma Ville, Akerman.

\section{References}

All This Can Happen. Dir. Siobhan Davies and David Hinton. UK, 2012. Digital Video.

Beach Party Animal. Dir. Liz Aggiss and Joe Murray. UK, 2012. Film.

Blaetz, Robin, ed. Women's Experimental Cinema: Critical Frameworks, London: Duke University Press, 2007.

Chaudhuri, Shohini. Feminist Film Theorists, Oxon: Routledge, 2002.

Carroll, Noël. "Toward a Definition of Moving-Picture Dance." International Journal of Screendance, 1 (Summer 2010). Accessed: September 2015.

http://journals.library.wisc.edu/index.php/screendance/issue/view/37/showToc

Distant Wars. Dir. Becky Edmunds. UK, 2013. Film. 
Festival Itinerante Agite Y Sirva (online). Accessed: July 2015.

http://www.agiteysirva.com/

Guy, Priscilla. "Review of the 1st Edition of Light Moves Festival: Screendance as a Question - All This Can Happen and the First Edition of the Light Moves Festival of Screendance." Posted: 21 November 2015.

https://screendance.wordpress.com/2015/11/21/review-of-the-1st-edition-of-lightmoves-festival/

If the Invader Comes. Dir. Dan Dobowitz and Fearghus O Conchuir. UK, 2014. Film.

International Screendance Festival in Durham / Movies by Movers (online). Accessed: July 2015. http://www.moviesbymovers.org/

International Videodance Festival of Burgundy / Festival International de Vidéo Danse De Bourgogne. Le Creusot, France, 18 May 2015.

Kappenberg, Claudia. "The politics of discourse in hybrid art forms." Art in Motion: Current Research in Screendance. Ed. Franck Boulègue, Marisa C Hayes, Cambridge: University of Wisconsin Digital Collections Center, 2015. 21-29.

Light Moves Festival of Screendance. Accessed: September 2015. http://www.lightmoves.ie/

Light Moves Festival of Screendance. Curated and directed by Mary Wycherly and Jürgen Simpson. Limerick, Ireland, 6-4 November 2014.

Nation for Two. Dir. Chaja Hertog and Nir Nadler. Netherlands, 2012. Film.

On Animal Locomotion. Dir. Johan van der Keukeun, Netherlands, 1994. Film.

Pearlman, Karen. Cutting Rhythms: Shaping the Film Edit, Burlington: Foca Press, 2009.

Playtime. Dir. Jacques Tati. France, 1967. Film.

Russian Ark. Dir. Alexander Sokurov. Russia/Germany, 2002. Film.

Réalisatrices Équitables. Accessed: September 3rd 2016. http://realisatricesequitables.com

Saute ma Ville. Dir. Chantal Akerman. Belgium, 1968. Film.

Temps/Travail. Dir. Johan van der Keuken, Netherlands, 1999. Film.

Vanishing Point. Dir. Beate Hecher and Markus Keim. Austria, 2010. Film. 